\title{
2021 Handbook of Florida Water Regulation: Florida Water Management Districts ${ }^{1}$
}

\author{
Michael T. Olexa, Tatiana Borisova, and Jana Caracciolo
}

\section{Preface}

This handbook is designed to provide an accurate, current, and authoritative summary of the principal federal and state (Florida) laws that directly or indirectly relate to agriculture. This handbook provides a basic overview of the many rights and responsibilities that farmers and farmland owners have under both federal and state laws as well as the appropriate contact information to obtain more detailed information. However, the reader should be aware that because the laws, administrative rulings, and court decisions on which this handbook is based are subject to constant revision, portions of this publication could become outdated at any time. Several details of cited laws are also left out due to space limitations. This handbook is provided as an educational text for those interested in water use and water resource issues in Florida.

This handbook is distributed with the understanding that the authors are not engaged in rendering legal or other professional advice, and the information contained herein should not be regarded as a substitute for professional advice. This handbook is not all inclusive in providing information to achieve compliance with the federal and state laws and regulations governing water protection. For these reasons, the use of these materials by any person constitutes an agreement to hold harmless the authors, the UF/IFAS Center for Agricultural and Natural Resource Law, and UF/IFAS Extension for any liability claims, damages, or expenses that may be incurred by any person as a result of reference to or reliance on the information contained in this handbook. Note: UF/IFAS is the acronym for University of Florida, Institute of Food and Agricultural Sciences.

\section{FWMD Overview}

The five Florida water management districts (FWMDs) play a significant role in the regulation of water use in the state (Figure 1) and four core missions (Figure 2).



Figure 1. Florida's Five Water Management Districts

Credits: St. Johns River Water Management District (2017), About the District https://www.sjrwmd.com/about/maps/

1. This document is FE594, one of a series of the Food and Resource Economics Department, UF/IFAS Extension. Original publication date October 1998. Revised June 2017 and April 2021. Visit the EDIS website at https://edis.ifas.ufl.edu for the currently supported version of this publication.

2. Michael T. Olexa, professor, Food and Resource Economics Department, and director, UF/IFAS Center for Agricultural and Natural Resource Law; Tatiana Borisova, associate professor, Food and Resource Economics Department; and Jana Caracciolo, student, Levin College of Law; UF/IFAS Extension, Gainesville, FL 32611.

The Institute of Food and Agricultural Sciences (IFAS) is an Equal Opportunity Institution authorized to provide research, educational information and other services

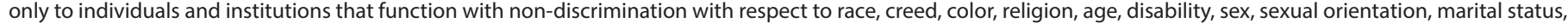

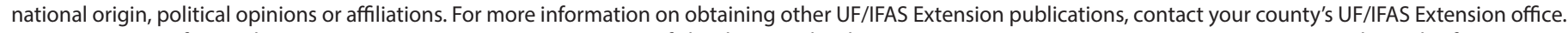
U.S. Department of Agriculture, UF/IFAS Extension Service, University of Florida, IFAS, Florida A \& M University Cooperative Extension Program, and Boards of County Commissioners Cooperating. Nick T. Place, dean for UF/IFAS Extension. 
Figure 2. Core Missions of Florida's Five Water Management Districts Credits: Based on DEP (2019), Water Management Districts https://floridadep.gov/water-policy/water-policy/content/watermanagement-districts

The Northwest, Suwannee River, and Saint Johns River Water Management Districts (NWWMD, SRWMD, and SJRWMD) were created as public agencies (pursuant to Chapter 373, Florida Statutes, known as the Florida Water Resources Act of 1972). The South Florida and the Southwest Florida Water Management District (SFWMD and SWFWMD) were created statutorily to address flooding and water shortage problems.

The four core missions (Figure 2) are based on the responsibilities of the FWMDs:

\section{Water Supply}

- Properly utilizing groundwater and surface water resources via water supply and demand planning and management.

- Creating a Regional Water Supply Plan that identifies future water supply needs for at least a 20-year planning horizon, and updating the Plan every five years.

- Assisting local governments in developing comprehensive local water management plans, particularly by providing data on water resources.

- Developing and piloting alternative water supply projects (i.e., water source alternatives to groundwater) within a restricted allocation area (for the list of eligible areas, see Chapter 373 Florida Statutes, section 373.037).

- Adopting rules incentivizing water conservation.

- Implementing water shortage emergency plans.

\section{Water Quality}

- Monitoring and assessing water quality.

- Funding water quality projects.

\section{Flood Protection and Floodplain Management}

- Managing surface water, groundwater, and related land.

- Regulating dams, impoundments, reservoirs, and other structures to alter surface water movement.
- Combating damage from floods, soil erosion, and excessive drainage.

- Maintaining navigable rivers and harbors.

- Participating in flood control programs and the reclamation, conservation, and protection of lands from water surplus or deficiencies.

4. Natural Systems

- Developing a priority list of water bodies to establish minimum water flows and water levels.

- Establishing minimum flows and water levels for water withdrawals that are not harmful to water resources or ecology.

- Establishing minimum water levels of groundwater and surface water.

\section{That is the structure of FWMDs?}

Each district is run by a governing board consisting of at least nine members. The members, who are selected from statutorily designated areas within each district, serve staggered four-year terms and are appointed by the governor and confirmed by the state senate. The governing board sets the policies that will best meet each district's needs. The governing board appoints the district's executive director, who directs all FWMD activities. Generally, an executive director is responsible for the operation of each district, including the implementation of policies and rules. Typically, each district is divided into divisions that handle the various permitting programs. Each district is fully equipped to conduct its own inspections, testing, and impact studies.

\section{What permits are issued by FWMDs?}

The powers of FWMD governing boards include administering the permit programs of Chapter 373, Florida Statutes. Permit programs are designed to insure that various human activities are conducted in a way that protects water resources. The FWMDs are responsible for the following permitting:

- Permits for consumptive uses of water; note that consumptive use is any use of water that reduces water availability in the source from which the water is withdrawn or diverted (e.g., consider withdrawals of groundwater); individual or general permits are used to regulate consumptive uses of water and protect water resources (For more information on consumptive use permits, please see FE604). 
- Well construction permits-such permits are required to install a water well; the permits are issued to insure that well construction and operation do not detrimentally impact water resources; the permits also ensure that wells meet durability and safety requirements (For more information on construction permits, please see FE603).

- Environmental resource permits-issued for the management and storage of surface waters, including stormwater runoff from construction and dredging and filling in wetlands. For more information on environmental resource permits, please see https://floridadep.gov/water/ submerged-lands-environmental-resources-coordination/ content/environmental-resource-permitting.

- Right-of-way occupancy-such permits are revocable licenses that are issued only in the South Florida Water Management District to protect the District's ability to effectively and safely use the canal and levee rights of way while providing for compatible public and private uses such as docks, fences, or walkways (For more information on right-of-way permits, please see https://www.sfwmd. gov/doing-business-with-us/permits/right-of-way).

- Works of the district-issued by Suwannee River Water Management District and South Florida Water Management District for proposed activities along major water bodies or watercourses, or projects that will discharge into certain drainage basins.

Each FWMD has specific criteria detailing the types of activities that require permits, the contents of permit applications, the procedures that surround the submission of applications, and areas specifically exempted from permitting requirements. More information about permits and permit requirements by the FWMDs can be found at the FWMD permitting portal (http://flwaterpermits.com/). waterbodies in each FWMD please visit the individual FWMD websites.

\section{What can FWMDs tax?}

Most indicative of their broad powers is the ability of FWMDs to levy ad valorem taxes (property taxes). Ad valorem taxes are levied based on the value of the property in question. The Florida Constitution establishes a millage cap, and millage rates are additionally limited by statute. A millage rate is one tenth of a percent, which equates $\$ 1$ in taxes for every $\$ 1$ in home value.

Each FWMD is different. As with other government tax provisions, a landowner's failure to pay can result in a lien on the taxed property, including the homestead, and ultimately, the vesting of title by tax forfeiture to the state.

\section{Acknowledgments}

The authors are indebted to the personnel of both state and federal agencies who provided their time and advice in the preparation of this handbook. We acknowledge Carol Fountain and Susan Gildersleeve at the University of Florida for their assistance in editing this handbook. We also acknowledge funding received for updating this publication from the James S. and Dorothy F. Wershow Agricultural Law Endowment.

\section{FWMD and Surface Water Improvement and Management (SWIM) Act}

In 1987, the Florida Legislature created the SWIM Act to protect, restore, and maintain Florida's surface water quality. The SWIM Act requires FWMDs to identify a list of priority waterbodies and develop plans to restore damaged ecosystems, prevent pollution from stormwater runoff and other sources, and educate the public. For a list of priority 